\title{
KERNIKTERUS NOT ASSOCIATED WITH HAEMOLYTIC DISEASE
}

\author{
BY \\ WONG HOCK BOON \\ From the Paediatric Unit, the General Hospital, Singapore
}

(RECEIVED FOR PUBLICATION AUguST 3, 1956)

Kernikterus (bile staining of brain nuclei at necropsy or jaundice causing neurological signs during life) not associated with haemolytic disease has been reported in the literature during the last few years. Black-Schaffer, Kambe, Furuta and Moloney (1954) described 13 cases which had died with kernikterus in Hiroshima during the neonatal period. Eleven of the 13 cases were premature infants. Aidin, Corner and Tovey (1950) likewise described 24 cases of kernikterus of which 23 were premature infants. Crigler and Najjar (1952) described a case of kernikterus in a family with an inherited bilirubin excretion defect in the liver, and Ehrlich and Ratner (1955) described a case of kernikterus in an infant with ' neonatal hepatitis'. Most of the published cases dealt with premature infants, but in the following series it will be shown that kernikterus in full-term infants not associated with iso-immunization is quite common in Singapore.

During the period from March, 1955, to December, 1955, 96 cases of jaundice during the first year of life were admitted to the Paediatric Unit of the General Hospital. In all these cases, the blood of the infant was tested for $\mathrm{Rh}$ and $\mathrm{ABO}$ antibodies and the Coombs antiglobulin test was done, but only two cases were found to be caused by isoimmunization (one due to $\mathrm{Rh}$ incompatibility and one due to $\mathrm{ABO}$ incompatibility). There were, however, 26 cases showing the symptoms, signs or pathological lesions of kernikterus. These 26 infants were all full term, under the age of 15 days on admission, and showed no evidence of iso-immunization. The criteria for diagnosis of these cases were a high serum bilirubin level with or without severe jaundice, with neurological signs, and evidence of bile-staining in the brain nuclei at necropsy in those who died. In more than half of the 26 cases the serum bilirubin was estimated after the manner of Hsia and his colleagues' modification of Evelyn and Malloy's method. The one-minute value corre- sponds to the 'direct-bilirubin', the normal for which is $0-0.2 \mathrm{mg} . \%$ for all ages, and the 30 -minute value is the 'indirect-bilirubin', the normal for which one week after birth is less than $0.8 \mathrm{mg}$. $\%$.

\section{Clinical Features}

The clinical features of these 26 cases resembled each other quite closely and a random selection of the case histories and the findings of a few of them will now be given.

Case 1. Y.Y.C., a 6-day-old Chinese baby girl, was admitted on May 16, 1955, with a history of fever with jaundice for one day before admission. She was the second child born at full term by normal delivery with a birth weight of $7 \mathrm{lb}$. The first child is alive and well. On examination she had a temperature of $101^{\circ} \mathrm{F}$. with severe jaundice and extensive thrush in the mouth. The liver was palpable one fingerbreadth, but the spleen was not felt. The limbs were stiff and the child had occasional fits. Investigations revealed the following: Haemoglobin $80 \%$ (Sahli); the peripheral blood showed no normoblasts; reticulocyte count $0.8 \%$; serum bilirubin level $32.5 \mathrm{mg}$. per $100 \mathrm{ml}$.; a blood Kahn test of the mother and infant was negative; both mother and infant were Rhesus positive, group B; the Coombs test was negative; no abnormal agglutinins were detected in the blood. The thrush infection was treated, the temperature subsided and the child survived. The jaundice disappeared completely after four months but the limbs were still slightly stiff and the milestones delayed. The child is still under observation.

Case 15. L.B.H., a 10-day-old Chinese baby boy, was admitted on April 10,1955, with a history of jaundice noticed on the third day of life and diarrhoea for four days before admission. He was the third child, and was born at full term with a normal delivery and a birth weight of $6 \mathrm{lb} .13 \mathrm{oz}$. The other two children are alive and well. On examination, he had a temperature of $99^{\circ} \mathrm{F}$. with severe jaundice and slight dehydration. The throat was injected and the umbilicus was septic. The liver was palpable one and a half fingerbreadths, but the spleen was not felt. Investigation revealed the following: 
Red cells 6.02 million, $\mathrm{Hb} 123 \%$. The peripheral blood showed no normoblastic reaction. The blood Kahn reactions of the mother and infant were negative. Both mother and infant were $\mathrm{Rh}$ positive but the mother was group $\mathrm{O}$ while the child was group $\mathrm{A}$; the Coombs test was negative and no abnormal agglutinins were detected. The child died the next day and necropsy showed bright yellow staining of the basal nuclei.

Case 27. S.P.Y., 10-day-old Chinese baby boy, was admitted on June 1, 1955, with a history of jaundice one day after birth and one day before admission he had fever with dyspnoea. He was the first child, born at full term with a normal delivery and a birth weight of $8 \mathrm{lb} .3 \mathrm{oz}$. On examination he had a temperature of $101^{\circ} \mathrm{F}$. with intense orange-yellow jaundice and a septic umbilicus. The liver was palpable one fingerbreadth but the spleen was not palpable. The peripheral blood showed no normoblastic reaction. The serum bilirubin level at $1 \mathrm{~min}$. was $5.8 \mathrm{mg}$. \%, at $30 \mathrm{~min} .35 .6 \mathrm{mg}$. The cephalin-cholesterol flocculation test was strongly positive. The blood Kahn reactions of mother and infant were negative. Both mother and child were $\mathrm{Rh}$ positive, group $\mathrm{A}$. The Coombs test was negative and no abnormal agglutinins were detected. The child died the next day and necropsy showed bile-staining of the brain nuclei.

Case 43. Q.A.K., a 7-day-old Chinese baby girl, was admitted on July 10,1955, with a history of jaundice one day after birth and fever with refusal of feeds one day before admission. She was the second child, born at full term with a normal delivery and a birth weight of $5 \mathrm{lb} .2 \mathrm{oz}$. The first child is alive and well. On examination she had a temperature of $100^{\circ} \mathrm{F}$. with severe jaundice. The liver was palpable one fingerbreadth below the costal margin but the spleen was not palpable. The peripheral blood showed no normoblastic reaction. The serum bilirubin level at $1 \mathrm{~min}$. was $0.5 \mathrm{mg}$. \%, at $30 \mathrm{~min} .43 .0 \mathrm{mg}$. \%. The cephalin-cholesterol flocculation test was negative. The mother was Rh positive, group $A$, while the infant was $R h$ positive, group $B$. The Coombs test was negative, and no abnormal agglutinins were detected. She died the same day and necropsy revealed kernikterus.

An analysis of the more common symptoms which brought the infants to hospital is shown in Table 1.

From the above, it is seen that in all of the 26 cases, there was a complaint of refusal of feeds, $73 \%$ had fever, $42.3 \%$ had vomiting, $19 \cdot 2 \%$ presented with breathlessness and $15.4 \%$ had fits.

It is seen that every case exhibited jaundice, $73 \%$ of them were drowsy, $61.5 \%$ had manifest concomitant infection, $46.1 \%$ had stiffness of limbs or neck and $7.7 \%$ were in different degrees of dehydration. In nearly all the cases the liver was palpable below the costal margin but this finding in itself is not of much significance because, in Singapore,
TABLE 1

PRESENTING SYMPTOMS

\begin{tabular}{|c|c|c|c|c|c|c|}
\hline No. & $\begin{array}{l}\text { Case } \\
\text { No. }\end{array}$ & $\begin{array}{l}\text { Fever } \\
(73 \%)\end{array}$ & $\begin{array}{c}\text { Refused } \\
\text { Feeds } \\
(100 \%)\end{array}$ & $\begin{array}{l}\text { Vomiting } \\
(42 \cdot 3 \%)\end{array}$ & $\begin{array}{c}\text { Dyspnoea } \\
(19 \cdot 2 \%)\end{array}$ & $\begin{array}{c}\text { Fits } \\
(15 \cdot 4 \%)\end{array}$ \\
\hline 1 & 1 & + & + & - & - & - \\
\hline 2 & 10 & - & + & + & - & - \\
\hline 3 & 13 & + & + & + & -- & - \\
\hline 4 & 15 & - & + & -- & - & - \\
\hline 5 & 17 & + & + & - & - & - \\
\hline 6 & 18 & + & + & - & - & - \\
\hline 7 & 22 & + & + & - & - & - \\
\hline 8 & 23 & + & + & -- & - & - \\
\hline 9 & 24 & + & + & + & - & - \\
\hline 10 & 27 & + & $\div$ & - & + & - \\
\hline 11 & 35 & - & + & + & - & + \\
\hline 12 & 37 & + & + & + & + & - \\
\hline 13 & 43 & + & + & - & - & - \\
\hline 14 & 47 & + & + & - & - & - \\
\hline 15 & 50 & + & + & + & + & - \\
\hline 16 & 59 & + & + & - & + & - \\
\hline 17 & 71 & - & + & - & - & - \\
\hline 18 & 73 & - & + & - & - & - \\
\hline 19 & 76 & + & + & + & - & - \\
\hline 20 & 80 & + & + & + & - & - \\
\hline 21 & 81 & + & + & - & - & + \\
\hline 22 & 82 & + & + & + & - & - \\
\hline 23 & 84 & - & + & + & - & - \\
\hline 24 & 85 & + & + & + & + & $-\cdot$ \\
\hline $\begin{array}{l}25 \\
26\end{array}$ & $\begin{array}{l}86 \\
88\end{array}$ & $\bar{t}$ & $\begin{array}{l}+ \\
+\end{array}$ & - & I & $\overline{-}$ \\
\hline & & & & & & \\
\hline
\end{tabular}

infants in the neonatal period invariably have palpable livers. In only four out of the 26 cases was the spleen palpable.

Tables 2 and 3 set out further data on the series. In Table 3, we see that 23 out of the 26 cases are Chinese. This is probably of no significance since the population of Singapore is predominantly Chinese and most of the admissions to the Unit are from the same race. The other three consist of Malay infants. Females number 12, while there are 14 males. The ages of those who died and at necropsy revealed kernikterus varied from 5 to 13 days. In five of these 26 cases the birth weight was not available, but in the remaining 21 cases all the birth weights were above $5 \mathrm{lb}$. and all were delivered at full term except for two babies whose gestation periods were 36 weeks. In Singapore the definition of prematurity includes infants weighing $5 \mathrm{lb}$. or less at birth, so that all the 21 cases would be considered mature in this series. The day when jaundice was first noticed varied from one to six days after birth. In those cases where the serum bilirubin level was estimated, the 30-minute value ranged from $23 \mathrm{mg}$. $\%$ to $54 \mathrm{mg}$. \%. In all the 26 cases, serology did not reveal any $\mathrm{Rh}$ or $\mathrm{ABO}$ incompatibility. The Coombs test was negative and no abnormal agglutinins were detected.

Histological sections were made of the livers and Professor R. Kirk examined them and reported as follows in three of the post-mortem cases:

Case 59. There is diffuse fatty change throughout the whole liver. The sinuses are greatly congested with 
TABLE 2

CLINICAL FINDINGS ON ADMISSION

\begin{tabular}{|c|c|c|c|c|c|c|c|c|c|}
\hline No. & $\begin{array}{l}\text { Case } \\
\text { No. }\end{array}$ & $\begin{array}{c}\text { Age in } \\
\text { Days on } \\
\text { Admission }\end{array}$ & $\begin{array}{l}\text { Infection } \\
(61.5 \%)\end{array}$ & $\begin{array}{l}\text { Jaundice } \\
(100 \%)\end{array}$ & $\begin{array}{c}\text { Muscular } \\
\text { Hypertonicity } \\
(46 \cdot 1 \%)\end{array}$ & Drowsiness & Dehydration & Liver & Spleen \\
\hline & 1 & & Thrush & + & + & + & - & 1 f.b. & n.p. \\
\hline 2 & 10 & 4 & - & + & . & + & - & 2 f.b. & $\mathrm{n} \mathrm{p}$ \\
\hline$\overline{3}$ & 13 & 3 & Conjunctivitis & + & + & + & - & 专 f.b. & n.p. \\
\hline $\begin{array}{l}4 \\
5\end{array}$ & $\begin{array}{l}15 \\
17\end{array}$ & $\begin{array}{r}10 \\
9\end{array}$ & $\begin{array}{l}\text { Of umbilicus } \\
\text { Coniunctivitis }\end{array}$ & \pm & 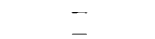 & \pm & \pm & $l_{2}^{\frac{1}{2}}$ f.b. & n.p. \\
\hline 6 & 18 & 6 & & + & - & - & - & $\frac{1}{2}$ f. f. & 1 f.b. \\
\hline 7 & 22 & 4 & $\begin{array}{l}\text { Thrush } \\
\text { Of }\end{array}$ & + & - & - & - & 2 f.b. & n.p. \\
\hline $\begin{array}{l}8 \\
9\end{array}$ & 23 & 6 & Of umbilicus & + & - & \pm & 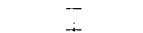 & 2 f.b. & n.p. \\
\hline 10 & 27 & 10 & $\begin{array}{l}\text { Pfaryngitis } \\
\text { Of umbilicus }\end{array}$ & I & - & t & E & 1 f.b. & $\begin{array}{l}\text { n.p. } \\
\text { n.p. }\end{array}$ \\
\hline 11 & 35 & 6 & Of umbilicus & + & + & + & - & & n.p. \\
\hline 12 & 37 & 3 & Of umbilicus & + & - & I & - & f.b. & n.p. \\
\hline 14 & 47 & 5 & Pharyngitis & + & + & 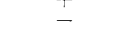 & - & $\begin{array}{l}1 \text { f.b. } \\
\text { f. }\end{array}$ & $\begin{array}{l}\text { n.p. } \\
\text { n.p. }\end{array}$ \\
\hline 15 & 50 & 12 & Of umbilicus & - & - & $\because$ & - & $\frac{1}{2}$ f.b. & n.p. \\
\hline 10 & 71 & 6 & Pneumonia & + & + & + & - & $\begin{array}{l}\text { n.p. } \\
\text { n.p. }\end{array}$ & n.p. \\
\hline 18 & 73 & 7 & - & - & + & + & - & 1 f.b. & n.p. \\
\hline 19 & 76 & $\begin{array}{l}6 \\
8\end{array}$ & Pneumonia & + & - & - & - & 1 f.b. & n.p. \\
\hline 21 & 81 & $\begin{array}{r}8 \\
14\end{array}$ & Pharyngitis & + & + & - & $=$ & $\begin{array}{l}2 \\
1 \text { f.b. } \\
\text { f.b. }\end{array}$ & $\begin{array}{l}\text { f.b. } \\
\text { n.p. }\end{array}$ \\
\hline 22 & 82 & 5 & - & + & + & + & - & 1 f.b. & n.p. \\
\hline $\begin{array}{l}23 \\
24\end{array}$ & 85 & 8 & 二 & + & $\begin{array}{l}T \\
+\end{array}$ & $\mp$ & $\overline{-}$ & 3 f.b. & $\frac{1}{2}$ f.b. \\
\hline $\begin{array}{l}25 \\
26\end{array}$ & $\begin{array}{l}86 \\
88\end{array}$ & $\begin{array}{l}3 \\
6\end{array}$ & Of umbilicus & + & + & + & $\bar{z}$ & $\begin{array}{l}1 \text { f.b. } \\
1 \text { f.b. }\end{array}$ & $\begin{array}{l}\frac{1}{2} \text { f.b. } \\
\text { n.p. }\end{array}$ \\
\hline & & & & & & & & & \\
\hline
\end{tabular}

$t=$ positive
$-=$ negative $n \cdot p_{0}=$ not palpable

f.b. = fingerbreadth

TABLE 3

FURTHER DATA ON THE SERIES

\begin{tabular}{|c|c|c|c|c|c|c|c|c|c|c|c|c|c|}
\hline \multirow{3}{*}{ No. } & \multirow{3}{*}{$\begin{array}{c}\text { Case } \\
\text { No. }\end{array}$} & \multicolumn{2}{|c|}{ Age in Days } & \multirow{3}{*}{ Sex } & \multirow{3}{*}{ Race } & \multirow{3}{*}{$\begin{array}{l}\text { Alive } \\
\text { (A) } \\
\text { or } \\
\text { Died } \\
\text { (D) }\end{array}$} & \multirow{3}{*}{$\begin{array}{c}\text { Day after } \\
\text { Birth when } \\
\text { Jaundice } \\
\text { First } \\
\text { Noticed }\end{array}$} & \multirow{3}{*}{$\begin{array}{l}\text { Birth } \\
\text { Weight } \\
\text { (lb. oz.) }\end{array}$} & \multirow{3}{*}{$\begin{array}{c}\text { Period } \\
\text { of } \\
\text { Gestation }\end{array}$} & \multirow{2}{*}{\multicolumn{2}{|c|}{$\begin{array}{c}\text { Serum } \\
\text { Bilirubin } \\
(\mathrm{mg} . \text { per } 100 \mathrm{ml} .)\end{array}$}} & \multirow{3}{*}{$\begin{array}{l}\mathrm{Hb} \% \\
\text { (Sahli) }\end{array}$} & \multirow{3}{*}{$\begin{array}{c}\text { Cephalin- } \\
\text { Cholesterol } \\
\text { Liver } \\
\text { Function } \\
\text { Test }\end{array}$} \\
\hline & & \multirow{2}{*}{$\underset{\substack{\text { Andmis- } \\
\text { sion }}}{\text { On }}$} & \multirow{2}{*}{$\begin{array}{c}\text { At } \\
\text { Death }\end{array}$} & & & & & & & & & & \\
\hline & & & & & & & & & & $1 \mathrm{~min}$. & $30 \mathrm{~min}$. & & \\
\hline $\begin{array}{r}1 \\
2 \\
3 \\
4 \\
5 \\
6 \\
7 \\
8 \\
9 \\
10 \\
11 \\
12 \\
13 \\
14 \\
15 \\
16 \\
17 \\
18 \\
19 \\
20 \\
21 \\
22 \\
23 \\
24 \\
25 \\
26\end{array}$ & $\begin{array}{l}1 \\
10 \\
13 \\
15 \\
17 \\
18 \\
22 \\
23 \\
24 \\
27 \\
35 \\
37 \\
43 \\
47 \\
50 \\
59 \\
71 \\
73 \\
76 \\
80 \\
81 \\
82 \\
84 \\
85 \\
86 \\
88\end{array}$ & $\begin{array}{r}6 \\
4 \\
3 \\
10 \\
9 \\
6 \\
4 \\
6 \\
11 \\
10 \\
6 \\
3 \\
7 \\
5 \\
12 \\
11 \\
6 \\
7 \\
6 \\
8 \\
14 \\
5 \\
3 \\
8 \\
3 \\
6\end{array}$ & $\begin{array}{r}-5 \\
5 \\
10 \\
9 \\
7 \\
5 \\
6 \\
12 \\
11 \\
8 \\
5 \\
8 \\
13 \\
11 \\
7 \\
8 \\
6 \\
- \\
5 \\
9 \\
5 \\
\end{array}$ & $\begin{array}{l}\mathbf{F} \\
\mathbf{M} \\
\mathbf{M} \\
\mathbf{M} \\
\mathbf{F} \\
\mathbf{F} \\
\mathbf{M} \\
\mathbf{M} \\
\mathbf{F} \\
\mathbf{M} \\
\mathbf{F} \\
\mathbf{M} \\
\mathbf{F} \\
\mathbf{F} \\
\mathbf{F} \\
\mathbf{M} \\
\mathbf{M} \\
\mathbf{M} \\
\mathbf{M} \\
\mathbf{F} \\
\mathbf{F} \\
\mathbf{M} \\
\mathbf{F} \\
\mathbf{F} \\
\mathbf{M} \\
\mathbf{M}\end{array}$ & 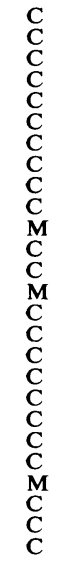 & $\begin{array}{l}\text { A } \\
\text { A } \\
\text { D } \\
\text { D } \\
\text { D } \\
\text { D } \\
\text { D } \\
\text { D } \\
\text { D } \\
\text { D } \\
\text { D } \\
\text { D } \\
\text { D } \\
\text { A } \\
\text { D } \\
\text { D } \\
\text { D } \\
\text { D } \\
\text { D } \\
\text { A } \\
\text { A } \\
\text { D } \\
\text { A } \\
\text { D } \\
\text { D } \\
\text { A }\end{array}$ & $\begin{array}{l}5 \\
2 \\
2 \\
3 \\
1 \\
3 \\
2 \\
4 \\
6 \\
1 \\
4 \\
1 \\
1 \\
4 \\
2 \\
+ \\
2 \\
1 \\
+ \\
6 \\
3 \\
1 \\
2 \\
1 \\
1 \\
5\end{array}$ & 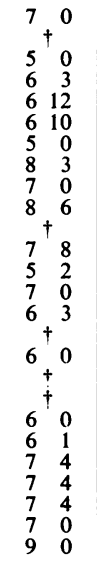 & $\begin{array}{c}\text { Full term } \\
+ \\
\text { Full term } \\
\text { Full term } \\
\text { Full term } \\
\text { Full term } \\
36 \text { wk. } \\
\text { Full term } \\
\text { Full term } \\
\text { Full term } \\
+ \\
\text { Full term } \\
\text { Full term } \\
\text { Full term } \\
\text { Full term } \\
\dagger \\
\text { Full term } \\
36 \text { wk. } \\
\quad+ \\
\text { Full term } \\
\text { Full term } \\
\text { Full term } \\
\text { Full term } \\
\text { Full term } \\
\text { Full term } \\
\text { Full term }\end{array}$ & $\begin{array}{l}6 \cdot 6 \\
* \\
* \\
* \\
* \\
* \\
* \\
* \\
5 \cdot 8 \\
8 \cdot 3 \\
5 \cdot 0 \\
0 \cdot 5 \\
12 \\
2 \\
* \\
* \\
* \\
* \\
10 \\
* \\
* \\
9 \cdot 4 \\
3 \cdot 2 \\
0 \\
4 \cdot 5\end{array}$ & $\begin{array}{c}32 \cdot 5 \\
* \\
* \\
* \\
* \\
* \\
* \\
* \\
35 \cdot 6 \\
30 \cdot 0 \\
28 \cdot 8 \\
43 \cdot 0 \\
37 \\
23 \\
* \\
* \\
* \\
* \\
37 \cdot 5 \\
* \\
* \\
54 \\
48 \\
23 \\
47 \cdot 8\end{array}$ & $\begin{array}{c}80 \\
75 \\
75 \\
120 \\
* \\
125 \\
* \\
* \\
* \\
* \\
140 \\
80 \\
* \\
* \\
* \\
* \\
* \\
* \\
* \\
88 \\
* \\
* \\
78 \\
* \\
92 \\
70\end{array}$ & $\begin{array}{c}* \\
* \\
* \\
* \\
* \\
* \\
* \\
++++ \\
\text { Negative } \\
\text { Negative } \\
\text { Negative } \\
\text { Negative } \\
++ \\
* \\
* \\
* \\
* \\
\text { Negative } \\
* \\
* \\
\text { Negative } \\
* \\
* \\
\text { Negative }\end{array}$ \\
\hline
\end{tabular}


blood, showing many nucleated red cells. The portal tracts show early diffuse infiltration with mononuclear cells. The architecture of the liver structures is normal and well maintained.

Case 85. Some diffuse fatty change. The portal tracts are infiltrated with cells and in places show an excessive amount of fibrous tissue. The liver cells stain very irregularly and the infiltration, mainly of mononuclear cells, extends inwards from the portal tracts into the substance of the liver lobules. Congestion not specially marked but nucleated red cells noticeable.

Case 43. The portal tracts are infiltrated with mononuclear cells. The liver cells show diffuse fatty change. Congestion not specially marked. Some nucleated red cells are visible.

He summarizes the findings thus: "There is nothing specific in these findings. The only constant pathological change is the fatty change seen in the livers.

' The presence of nucleated red cells in the vessels and sinuses is probably due to the continued haemopoiesis there and not to erythroblastosis foetalis as this condition is definitely excluded by the blood examination in these cases.'

\section{Discussion}

The Cause of Kernikterus. Most of the theories of the causation of kernikterus can be summarized into two main groups: (1) The concept that the brain is damaged first and then some form of bilirubin is fixed in these injured tissues; (2) that bilirubin and its products damage the brain nuclei themselves.

The proponents of the first theory considered birth trauma, anaemia, cerebral anoxia, vascular occlusions, etc., as the damaging aetiological agent. In the present series there was no evidence of birth trauma and delivery had been normal. The infants were delivered either in the Kandang Kerbau Maternity Hospital or by qualified midwives in the mothers' own homes. The haemoglobin level in our series showed that whenever it was estimated it had never been below $70 \%(100 \%=14.8 \mathrm{~g} . \mathrm{Hb})$. Claireaux's (1950) figures for his infants with kernikterus ranged from $120 \%$ to $70 \%$. Pickles (1949) has pointed out that in the most anaemic newborn and stillborn infants with hydrops foetalis resulting from haemolytic disease of the newborn there was no jaundice or any signs of bile staining of the brain nuclei. The argument that premature babies are more prone to kernikterus than full-term infants due to their greater liability to cerebral anoxia and hence brain damage is not really tenable; according to Smith (1951), in animal experiments, newborn animals can survive anoxia for periods - 40 times as long as adults, and the more premature the animal, the more resistant it is to anoxic effects.
This resistance is probably due to the relatively more anaerobic carbohydrate metabolism in the foetal stage being carried over into the neonatal period. The strongest evidence against a preinjury to the brain is the well-established observation that exchange transfusions if done early enough bring about total recovery with no neurological sequelae in cases of haemolytic disease of the newborn.

It is therefore more likely that bilirubin or its products in excessive amounts in the blood are deposited in the brain tissue and cause the injury directly. Najjar, quoted by Black-Schaffer et al. (1954), advances the theory that the bilirubin molecule is an analogue of heme and may in this sense be able to compete with heme at the active surface of the heme-containing enzymes, such as cytochromes, and may produce damage to the brain cells.

Accepting the theory that kernikterus in the newborn may be caused by a bilirubinaemia, the question arises as to what level the bilirubin should rise in the blood before it passes the blood-brain barrier. Mollison and Cutbush (1954) found that with plasma concentrations of total bile pigment of 19 to $24 \mathrm{mg}$. per $100 \mathrm{ml}$. one baby in 13 suffered brain damage, and that this is increased to four out of 12 if the amount of pigment rose to 24 to $29 \mathrm{mg}$. per $100 \mathrm{ml}$. Above that amount, the majority of infants were affected. Hsia, Allen, Gellis and Diamond (1952) in their series of cases of haemolytic disease of the newborn considered that approximately $50 \%$ of those infants with a serum bilirubin level of more than $30 \mathrm{mg}$. per $100 \mathrm{ml}$. are liable to kernikterus. In our present series, kernikterus occurred when the serum bilirubin level was definitely high. The lowest was $23 \mathrm{mg}$. \% and the highest $54 \mathrm{mg}$. \% (Fig. 1) in the 12 cases where the serum bilirubin was estimated. The serum bilirubin could not be estimated in the rest because they were admitted in extremis.

The type of bilirubin causing kernikterus is the 'indirect form' which in our series is represented by the '30-minute bilirubin'. But the actual type of pigment which is deposited in the kernikteric brains has not been definitely established. Vogel (1953) extracted the pigment from the brains of three infants dying of kernikterus and showed by electrophotometry that it resembled crystalline mesobilirubin.

Cause of Kernikterus in Present Series. In the present series, haemolytic disease was excluded by all available methods, and none of the 26 cases were premature by weight and only two were immature 


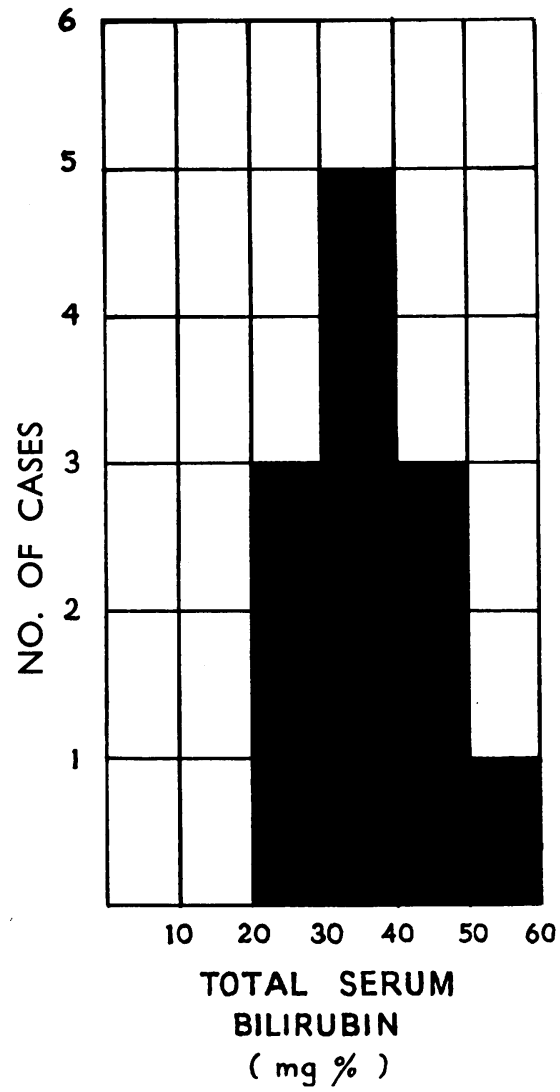

FIG. 1.

by gestation period. It may be significant that $61.5 \%$ had demonstrable foci of infection, which may affect the liver, producing a toxic hepatitis, and when this is associated with the immature liver of the newborn and the physiological excessive breakdown of red cells, then an excess of bilirubin will accumulate in the blood. However, it will be noted that the age of onset of the jaundice in 14 out of our 26 cases was in the first two days of life which is very early for a toxic hepatitis from sepsis.

We also considered the possibility of a virus infection of the liver, and a few samples of blood from these cases were injected into mice by Dr. K. A. Lim, but no conclusive results were obtained. Stokes, Berk, Malamut, Drake, Barondess, Bashe, Wolman, Farquhar, Bevan, Drummond, Maycock, Capps and Bennett (1954) had a case of 'viral hepatitis' in an infant where the serum of infant and mother was injected into human volunteers and $40-60 \%$ of the volunteers developed hepatitis after an incubation period varying from 74 to 100 days, and they considered that it is possible for an infant to be affected with viral hepatitis while in utero, i.e., a foetal viral hepatitis. Except for this single instance no further proof has been obtained and as the matter now stands this problem remains unsolved.

Stokes, Wolman, Blanchard and Farquhar (1951), Craig and Landing (1952), Dible, Hunt, Pugh, Steingold and Wood (1954), Gellis, Craig and Hsia (1954), and Ehrlich and Ratner (1955) have described cases of neonatal jaundice, and at necropsy a 'giant-cell cirrhosis' was found. In one of the two cases described by Ehrlich and Ratner, there was evidence of kernikterus at necropsy. In our cases, no evidence of 'giant-cell cirrhosis' was found.

All our cases were from the lower-income groups with mothers subsisting on suboptimal diets, and although we have not been able to go into the diets of the mothers thoroughly, interrogation usually revealed that their diet consisted of highly-polished rice, vegetables, with occasional fish and rarely any meat - a diet that is highly deficient in protein, and we wonder whether this poor diet may have resulted in infants being born with livers functioning inefficiently. Kwashiorkor in a mild form does exist in Singapore, and the majority of children coming to necropsy have fatty livers irrespective of the cause of death. Furthermore, the constant feature in the histological sections of the livers of the above cases was a diffuse fatty change. It could be that these infants were born with livers which were inefficient in dealing with the normal physiological bilirubinaemia as a result of protein malnutrition in the mothers.

Management. We find that once the stage of clinical kernikterus is reached, most of them die in spite of any treatment. Twenty-one out of the 26 cases died, with a mortality rate of $81 \%$. If, as discussed above, the pathology resides in the liver, then a careful prophylactic diet should be advised for the mother. All infections in the newborn should be promptly treated before feeding difficulties and vomiting cause further depletion of liver resources. In one patient (Case 86), who was very ill, an exchange transfusion was carried out but the patient died.

\section{Summary}

Twenty-six cases of kernikterus of non-haemolytic origin in the newborn infant occurring in the Paediatric Unit of the General Hospital, Singapore, during the period March, 1955, to December, 1955, are described.

The incidence of these cases in full-term, mature infants as distinct from previous reports mainly in premature infants is stressed. 
The mechanism of kernikterus in general is briefly described and the probable mode of the production of kernikterus in the present series discussed. It is suggested that in some of these cases the offending pigment, which is the 'indirect bilirubin', is excessively raised as a result of the normal physiological breakdown of red cells after birth superimposed on an inefficient liver due to protein malnutrition in the mother. Sepsis may have been a contributory factor.

I am indebted to Dr. C. Elaine Field, paediatric specialist, General Hospital, Singapore, for considerable help and advice in the preparation of this paper; to Professor R. Kirk, Professor of Pathology, University of Malaya, for the histological study of the liver sections; to Dr. P. C. Leong, biochemist, General Hospital, Singapore, for the serum bilirubin estimations; to Dr. A. Gibson-Hill, medical officer, Blood Transfusion Service, Singapore, for the serological examinations; to Dr. K. A. Lim, Senior Lecturer, Department of Bacteriology, University of Malaya, for the mice inoculations; and to the Director of Medical Services, Singapore, for permission to publish.
REFERENCES

Aidin, R., Corner, B. and Tovey, G. (1950). Lancet, 1, 1153. Black-Schaffer, B., Kambe, S., Furuta, M. and Moloney, W. C. (1954). Amer. J. Dis. Child., 87, 737.

Cathie, I. A. B. (1946). Archives of Disease in Childhood, 21, 229. Claireaux, A. (1950). Ibid., 25, 71.

Craig, J. M. and Landing, B. H. (1952). A.M.A. Arch. Path., 54,321

Crigler, J. F., Jr. and Najjar, V. A. (1952). Pediatrics, 10, 169.

Dible, J. H., Hunt, W. E., Pugh, V. W., Steingold, L. and Wood, J. H.' F. (1954). J. Path. Bact., 67, 195

Ehrlich, J. C. and Ratner, I. M. (1955). Amer. J. Path., 31, 1013.

Gellis, S. S., Craig, J. M. and Hsia, D. Y-Y. (1954). Amer. J. Dis. Child., 88, 285.

- and Hsia, D. Y-Y. (1955). Pediat. Clin. N. Amer., p. 449.

Hsia, D. Y-Y., Allen, F. H., Jr., Gellis, S. S. and Diamond, L. K. (1952). New Engl. J.' Med., 247, 668.

Lathe, G. H. (1955) Brit med. J. 1, 192

Mollison, P. L. and Cutbush, M.'(1954). Recent Advances in Paediatrics, ed. D. Gairdner, p. 110. London. Paediatrics, ed. D. Gairdner, p. 110, Lo
and Walker, W. (1952). Lancet, 1, 429.

${ }_{\text {Pickles, M. M. (1949). Haemolytic Disease of the Newborn. Oxford. }}$ Smith, C. A. (1951). The Physiology of the Newborn Infant, 2nd ed., pp. 141-52. Springfield, Illinois.

Stokes, J., Jr., Wolman, I. J., Blanchard, M. C. and Farquhar, J. D. (1951). Amer. J. Dis. Child., 82, 213.

—, Berk, J. E., Malamut, L. L., Drake, M. E., Barondess, J. A., Bashe, W. J., Wolman, I., J., Farquhar, J. D., Bevan, B., Drummond, R. J., Maycock, W. d'A., Capps, R. B. and Bennett, A. M. (1954). J. Amer. med. Ass., 154, 1059.

Vogel, F. S. (1953). Amer. J. Path., 29, 582.

Weech, A. A. (1947). Advances in Pediatrics, vol. 2, p. 346.

Zimmerman, H. M. and Yannet, H. (1933). Amer. J. Dis. Child., 45, 740 . 